\title{
PROTEINS OF THE SEMINIFEROUS TUBULE FLUID IN MAN-EVIDENCE FOR A BLOOD-TESTIS BARRIER
}

\author{
AARNE I. KOSKIMIES, MARTTI KORMANO AND \\ OLOF ALFTHAN \\ Department of Anatomy, University of Helsinki, and \\ Department of Urology of the Second Surgical Clinic, \\ University Central Hospital, Helsinki, Finland
}

(Received 16th December 1971)

\begin{abstract}
Summary. Seminiferous tubule fluid was collected by micropuncture from ten human testes immediately after orchidectomy and subjected to high resolution step gradient acrylamide gel electrophoresis. The protein patterns of the fluid were compared with those of serum and intratesticular lymph. The seminiferous tubule fluid always contained a number of proteins not seen in serum or in testicular lymph and a few proteins which were electrophoretically identical with those in serum. The bulk of these relatively weak serum bands consisted of albumin. Disturbance of spermatogenesis did not influence either the appearance of specific proteins or the degree of serum contamination.

The present results are interpreted to mean that in man, as in animals, there is an effective blood-testis barrier. The specific proteins of the seminiferous tubules may be elaborated by Sertoli cells.
\end{abstract}

\section{INTRODUCTION}

The seminiferous tubules secrete a fluid which carries the spermatozoa out of the testis and into the epididymis. The existence of such a fluid has been recognized for some time (von Mihalkovics, 1873; Stieda, 1877), and its circulation was studied microscopically either in normal testes (Rolshoven, 1936) or after ligation of the efferent ducts in experimental animals (Young, 1933). However, it has only recently been shown that the composition of the fluid is unique. This is due both to the existence of a barrier mechanism which prevents the entry of various substances into the seminiferous tubule and to secretory phenomena within the seminiferous epithelium (Setchell, 1971). Present knowledge of these phenomena is based on experimental studies only, mainly on rete testis fluid obtained by the implantation of a catheter (Voglmayr, Waites \& Setchell, 1966). A difference in composition has been found between the primary secretion of the seminiferous tubules and the fluid contained in the rete testis (Tuck, Setchell, Waites \& Young, 1970; Kormano, Koskimies \& Hunter, 1971).

The protein content of the rete testis fluid of various animals is very low, from 1 to $8 \%$ of that of the blood plasma (Setchell, 1970a). Recently, we have 
found evidence that the protein concentration of the primary secretion of the seminiferous tubules is even lower (Kormano et al., 1971). The extent to which serum proteins are present in this fluid can be taken as an indication of the efficiency of the blood-testis barrier between the interstitial tissue and the intratubular lumen. On the other hand, if specific proteins are present, they may give important information about the secretory phenomena within the seminiferous epithelium.

There is abundant information on the various aspects of the blood-testis barrier and the protein composition of the testicular fluid in experimental animals. In man, however, it has not been established that a functional bloodtestis barrier exists, and little is known about the protein composition of human testicular fluid or what changes it may undergo in various pathological conditions. We therefore decided to use orchidectomy material to study the protein content of human seminiferous tubule secretion by high-resolution step gradient polyacrylamide gel electrophoresis.

\section{EXPERIMENTAL}

Samples of seminiferous tubule fluid were obtained from the testes of ten patients subjected to bilateral total orchidectomy because of primary carcinoma of the prostate with or without metastases (for details, see Table 1). Only one patient (No. 7) had received preoperative oestrogen hormone therapy. The operation was carried out under either local or general anaesthesia, depending on the patient's general condition. In the majority of cases, micropuncture was carried out under a dissecting microscope immediately after removal of the testes and was completed within $30 \mathrm{~min}$. Only one testis from each patient was used for examination. In some cases, the effect of a time lapse between orchidectomy and micropuncture was studied in samples taken up to $5 \mathrm{hr}$ after operation, the testis being kept at $4^{\circ} \mathrm{C}$ during the intervening period.

\section{Collection of fuids}

Seminiferous tubules were punctured with a glass capillary with an outer tip diameter of 20 to $30 \mu \mathrm{m}$. Two to four samples from the same testis were pooled to make a single sample for electrophoretic study. Intratesticular lymph was collected through an incision in the tunica albuginea by placing a glass capillary between the unperforated seminiferous tubules. In addition to the testicular lymph, each patient's serum (diluted 1:10) was studied for comparison.

\section{Electrophoresis}

All the samples, ranging in size from 0.5 to $1.0 \mu \mathrm{l}$, were absorbed onto cellulose acetate paper strips measuring $2 \times 3 \mathrm{~mm}$ and studied with the electrophoretic separation technique using a step-gradient, flat-bed acrylamide gel system as recommended by the manufacturer (ORTEC, 1970). This system utilizes a $0.75 \mathrm{M}$-tris-sulphate separating gel buffer, $\mathrm{pH} 9 \cdot 0$, the concentration of acrylamide at the origin being $4.5 \%$ and increasing by steps to $6 \%, 8 \%$ and $12 \%$. Both the upper and the lower tanks are filled with $0.065 \mathrm{M}$-tris- 
Proteins of the seminiferous tubule fluid in man

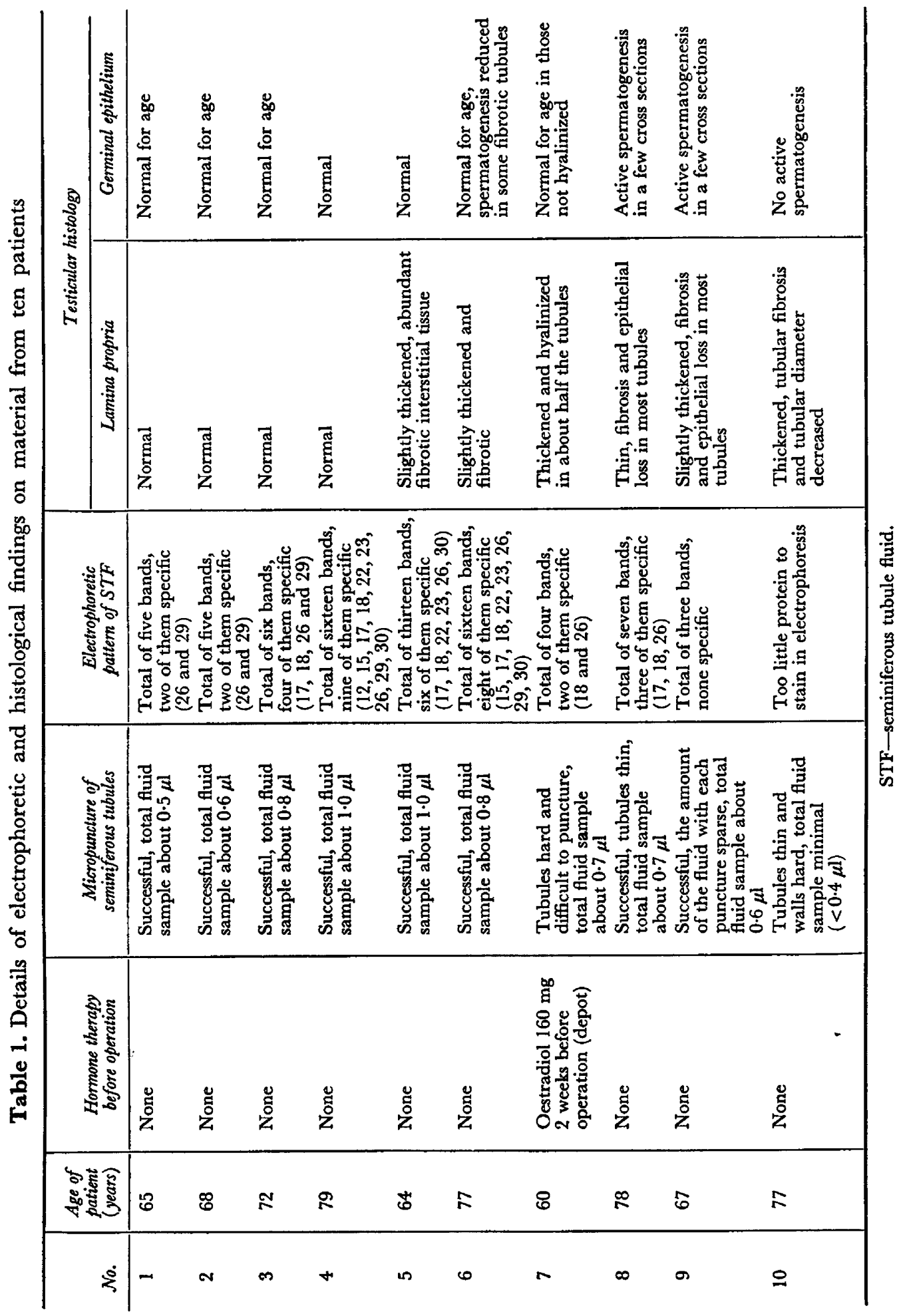


borate buffer, $\mathrm{pH} 9 \cdot 0$. The strips containing the samples are placed on the surface of the $4.5 \%$ gel and an $8 \%$ acrylamide gel cap is pressed against the upper surface of the sample containing the strips. The gel cap is made up of the same composition as the $8 \%$ acrylamide portion of the running gel, except that the buffer concentration is half that of the running gel. Constant power for the electrophoretic separation is provided by means of a pulsed constant power supply, in which the initial pulse rate is 75 pulses/sec. The pulse rate is increased by 75 pulses/sec at 5 -min intervals until 300 pulses/sec is reached. The capacitance is set at $1.0 \mu \mathrm{F}$ and the voltage at $280 \mathrm{~V}$. The total time-lapse for the run is $45 \mathrm{~min}$. The gel is removed and fixed in $12 \%$ trichloroacetic acid for $30 \mathrm{~min}$. After the gel slab has been rinsed five or six times in tap water, it is placed in a $0.20 \%$ aqueous solution of Coomassie Blue for $1 \mathrm{hr}$ at $37^{\circ} \mathrm{C}$. The gel is then rinsed in several changes of $10 \%$ acetic acid until no more dye is extracted.

\section{Histology}

After micropuncture of the tubules, the part of the testis involved (about $5 \times 5 \times 5 \mathrm{~mm}$ ) was excised, fixed in Bouin's fluid and embedded in paraffin wax. Sections $(5 \mu \mathrm{m}$ thick) were stained with PAS and haematoxylin-eosin.

\section{RESULTS}

A brief summary of the electrophoretic and histological findings for the material from each patient is given in Table 1. It is well known that the human testis always shows some degenerative seminiferous tubules (Tillinger, 1957; Suoranta, 1971). Division of the present material into normal and pathological groups was based on the histological picture of the area of the testis subjected to micropuncture and not according to the general appearance of the whole testis. The latter may show great histological variation and necessarily results in somewhat arbitrary division of the testes into normal and pathological (Suoranta, 1971).

\section{Normal testes}

Six of the testes (Nos 1 to 6 ) were regarded as histologically normal. In spite of the advanced age of the patients, these testes showed fully active spermatogenesis. In three, some thickening of the lamina propria was observed and one showed an increase of interstitial tissue.

In all serum samples, twenty-one different bands of varying intensity were observed on electrophoresis but, since there was also variation between individuals, each tubule fluid sample was compared with serum from the same patient. Testicular lymph proteins differed little from those of serum.

The largest samples of tubule fluid, up to $1.0 \mu \mathrm{l}$ (Nos 4 to 6 ), revealed up to sixteen different protein bands on electrophoresis. The final number of bands in these samples proved to depend critically on the volume of fluid obtained. The first samples, being only about $0 \cdot 5 \mu$, yielded many fewer bands (Table 1). Irrespective of the final number of protein bands, all samples were found to contain proteins with the same electrophoretic mobilities as some serum pro- 
teins and proteins apparently specific to the tubule fluid. In the most successful samples, there were seven to eight serum protein bands and six to nine specific bands.

Of the serum proteins, albumin was constantly the heaviest. Instead of the single albumin band typical of serum, albumin appeared as a moderately

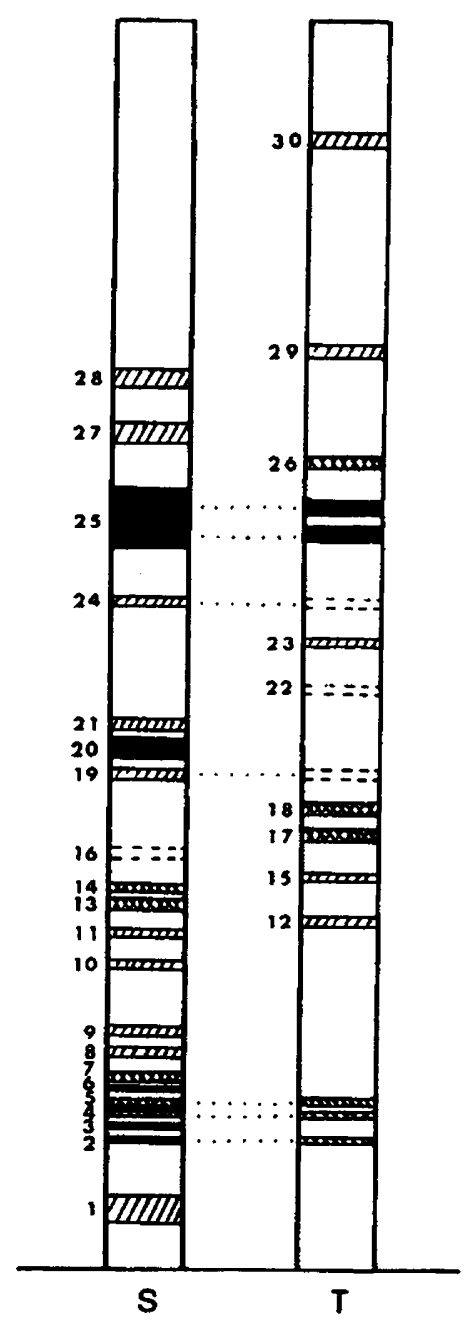

TEXT-FIG. 1. Diagram of the protein bands in polyacrylamide gel electrophoresis and the numbering used in the text. $S$, serum; $T$, seminiferous tubule fluid. Serum protein bands seen in the seminiferous tubule fluid are connected in the columns with dotted lines.

intense double band in the tubule fluid (Band 25 in Text-fig. 1). Other serum bands, when visible, were much weaker in tubule fluid than in serum. Serum bands Nos 2, 4 and 5 were the most constant serum proteins in tubule fluid, in addition to albumin.

Among the proteins specific to the seminiferous tubule fluid, the fast moving 
prealbumin bands were the most constant, at least two of them being observed in all the samples. In the best separations, up to three prealbumin bands were visible (Pl. 1, Fig. 1a). Another characteristic group of proteins in seminiferous tubule fluid was a double band with intermediate mobility (Nos 17 and 18). These bands proved to be the most intense given by specific proteins (Pl. 1, Fig. 1a). The other tubule-specific proteins were remarkably weak and could be identified only in the three most successful electrophoretic separations.

No essential change in the pattern was found after the testes had been kept up to $5 \mathrm{hr}$ at $4^{\circ} \mathrm{C}$.

\section{Pathological testes}

Of the four pathological testes, No. 7 showed tubular hyalinosis in about half the tubules and a thickened lamina propria in all the other tubules. Where spermatogenesis was taking place, it appeared normal. This was taken to indicate that the oestrogen given had caused no major changes. The tubules felt hard and were difficult to puncture and the fluid sample obtained was small. Even in this sample, however, the bands, although few, included tubulespecific and serum proteins (Table 1 ).

The testis of patient No. 8 had shrunken but thin-walled seminiferous tubules and severe loss of spermatogenic activity (Pl. 2, Fig. 2b). The small sample of tubule fluid still revealed a total of seven bands, three of which were specific for normal seminiferous tubule fluid (Pl. 2, Fig. 2a).

The testis of patient No. 9 showed spermatogenesis in only a few tubules, the rest being fibrotic. The electrophoretic procedure failed to show specific proteins.

The testis of patient No. 10 was completely fibrotic, and the amount of tubule fluid obtained was too small for electrophoretic separation.

\section{DISGUSSION}

These observations show that there is remarkably little passage of serum proteins into human seminiferous tubules. Most of the serum protein bands in seminiferous tubule fluid are either albumin or $\alpha$-macroglobulins (Johnson \& Setchell, 1968). No quantitative measurements of the total protein content of the seminiferous tubule fluid were made, but when the electrophoretic pattern is compared with that of rat tubule fluid (Kormano et al., 1971), the intensity of staining seems to be of the same order. From the electrophoretic pattern, it can be seen that many of the serum proteins are not present in the seminiferous tubule fluid in detectable quantities.

The fluid secreted by the human seminiferous tubules was seen to contain a number of specific proteins. Evidence of specific protein within the ram rete testis fluid has already been obtained by Johnson \& Setchell (1968). A recent study on the rat testis (Kormano et al., 1971) revealed that there are a number of such proteins and that these have a constant electrophoretic pattern. On electrophoresis of the tubule fluid of rat testes and that of normal human testes, the basic pattern of the specific proteins is seen to be remarkably similar. For 
PLATE 1

(a)
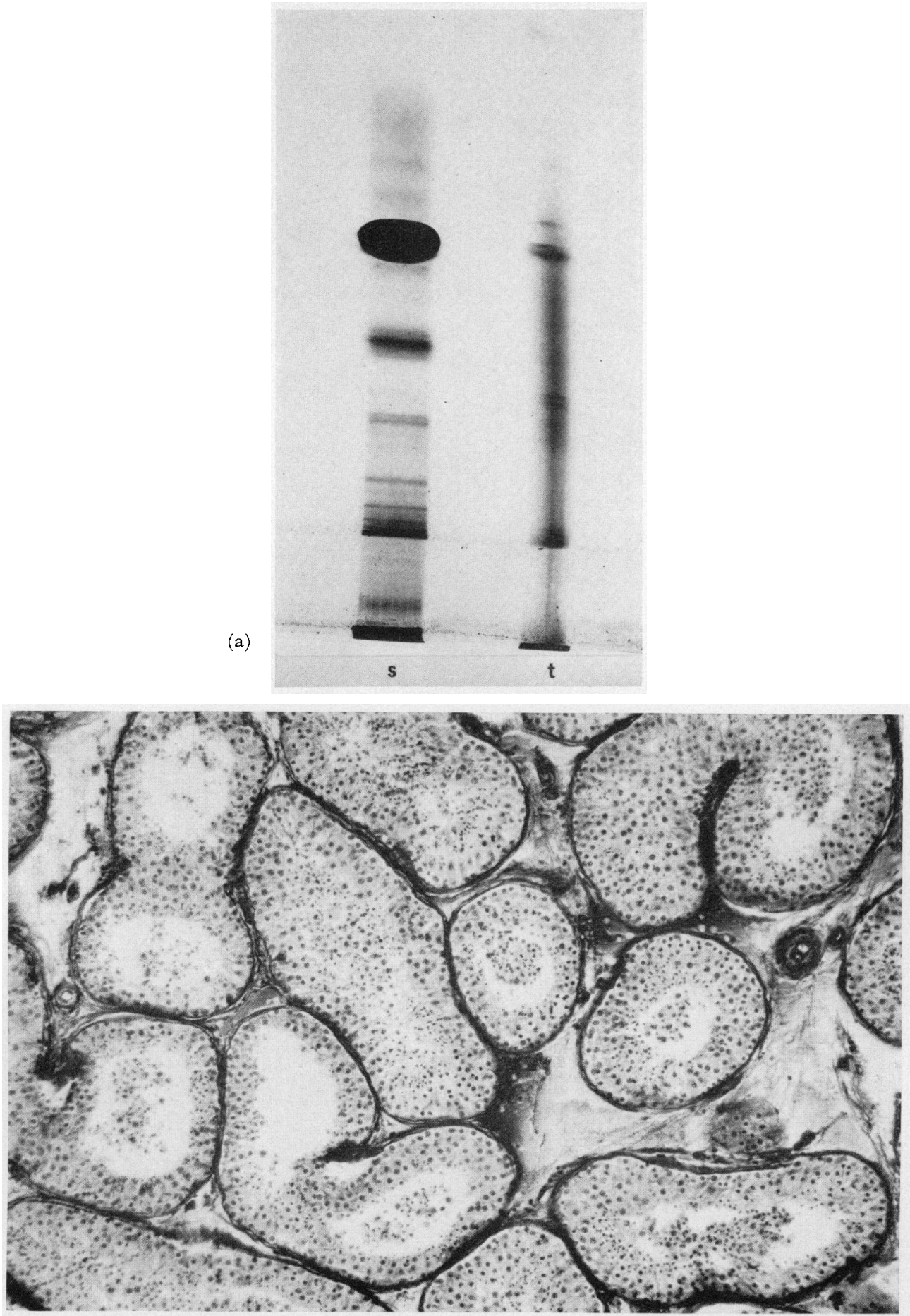

Fig. 1(a). Electrophoretic protein pattern of serum (s) and seminiferous tubule fluid (t) from patient No. 4.

Fig. 1(b). Histology of the testis from the same patient, showing normal seminiferous tubules and fully active spermatogenesis. $\times 100$.

(Facing p. 84) 
(a)
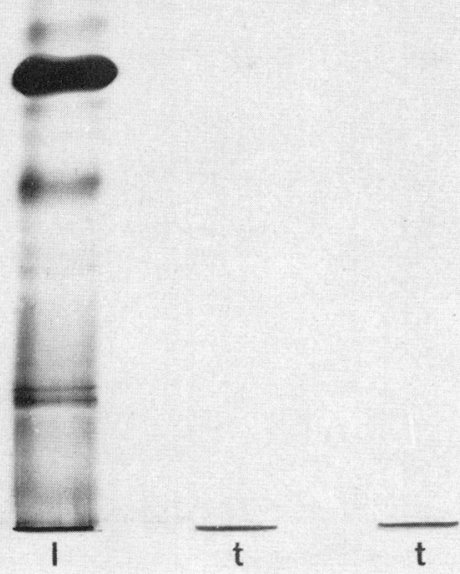

S

(b)

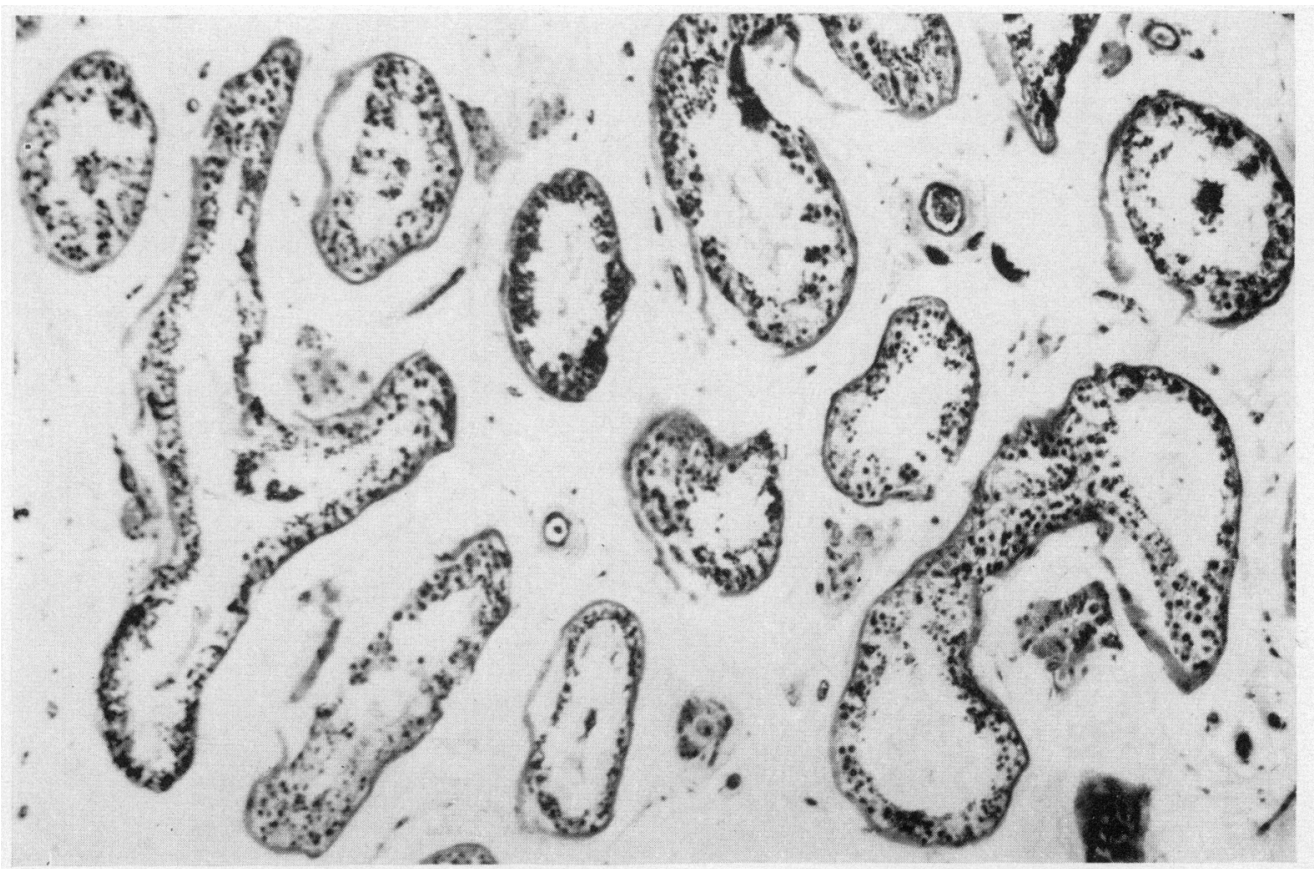

FIG. 2(a). Electrophoretic protein pattern of intratesticular lymph (l), seminiferous tubule fluid ( $t$ ) and serum (s) from patient No. 8.

Fig. 2(b). Histology of the testis from the same patient shows fibrosis and loss of epithelium in the tubules. No active spermatogenesis. $\times 100$. 
example, both rat and human tubule fluid contain several fast-moving proteins and both contain a group of intensely staining specific proteins with intermediate mobility.

The age of the patients in this study was rather high (mean age 70.7 years) and this, of course, may have influenced the results to some extent. However, there is nothing to suggest that age causes any major change in the general pattern, since this pattern seems to remain relatively constant even in pathologically changed tubules.

It is remarkable that there was no sign whatsoever of increased serum contamination in pathological tubules. In fact, the failure to demonstrate the pattern at its best was probably due to the small amount of fluid obtained from the hardened and shrunken tubules. According to Setchell (1970b), there is nothing to suggest a change in the rate of secretion of the seminiferous tubule fluid per unit weight of the testis in response to hypophysectomy in rats, although this causes a disturbance of the seminiferous epithelium, but cryptorchidism will cause a decrease in fluid secretion. On the other hand, conditions like cadmium injury (Johnson, 1969) and allergic orchitis (Johnson, 1970) increase the permeability of the blood-testis barrier.

Specific bands were visible even in fluid taken from severely degenerated tubules. This is in agreement with previous suggestions (Setchell, 1969; Kormano et al., 1971) that it may be the Sertoli cells that elaborate the specific proteins. In fact, these cells are the only ones which might be concerned with transport functions (Niemi \& Kormano, 1965). They apparently remain intact even when the rest of the spermatogenic epithelium degenerates.

The observations reported here are interpreted as evidence for the existence of a blood-testis barrier in man, which of course would be expected from the work done on various experimental animals.

Very recently, much new information has been obtained on the position and ultrastructure of the blood-testis barrier. Observations on interstitially and intravascularly injected particles suggest that, in rodent seminiferous tubules, the passage of larger particles is barred by the myoid cell layer. Smaller markers are less completely excluded by the continuous myoid layer seen in these animals but are arrested by the specialized junctions between adjacent Sertoli cells (Fawcett, Leak \& Heidger, 1970; Dym \& Fawcett, 1971). In the human testis, the seminiferous tubules are also surrounded by cells with the characteristics of contractile cells (Ross \& Long, 1966). These cells do not form a continuous coat connected by desmosomal junctions, but are often separated from each other by collagen fibres. There is, therefore, little morphological evidence of a barrier in the peritubular cell layers of the human testis. In agreement with Burgos, Vitale-Calpe \& Aoki (1970), our unpublished ultrastructural observations have shown that there are specialized junctions between the Sertoli cells in human seminiferous epithelium. Similar junctions in the rat function effectively as the final morphological sieve of the bloodtestis barrier (Dym \& Fawcett, 1971). It can be assumed that these junctions function in a similar fashion in the human testis. The observation that the permeability of the human blood-testis barrier does not increase, even when degenerative changes occur in the seminiferous epithelium, is compatible with 
the view that Sertoli cell junctions function as a barrier, since, in our experience, these junctions persist even in degenerated seminiferous tubules.

\section{ACKNOWLEDGMENTS}

This study is part of a research project on the relations between the circulation, spermatogenesis and the blood-testis barrier, and was supported financially by grants from the National Research Council for Medical Sciences, Finland, to A.I.K. and M.K.

\section{REFERENCES}

Burgos, M. H., Vitale-Calpe, R. \& Aoki, A. (1970) Fine structure of the testis and its functional significance. In: The Testis, Vol. I, p. 551. Eds. A. D. Johnson, W. R. Gomes and N. L. VanDemark. Academic Press, New York.

DYM, M. \& FAWCETT, D. W. (1971) Further observations on the numbers of spermatogonia, spermatocytes, and spermatids connected by intercellular bridges in the mammalian testis. Biol. Reprod. 4, 195.

FAwcetT, D. W., Leak, L. V. \& Heidger, P. M., JR (1970) Electron microscopic observations on the structural components of the blood-testis barrier. F. Reprod. Fert., Suppl. 10, 105.

Johnson, M. H. (1969) The effect of cadmium chloride on the blood-testis barrier of the guinea-pig. 7. Reprod. Fert. 19, 551.

Johnson, M. H. (1970) Changes in the blood-testis barrier of the guinea-pig in relation to histological damage following iso-immunization with testis. 7. Reprod. Fert. 22, 119.

Johnson, M. H. \& Setchell, B. P. (1968) Protein and immunoglobulin content of rete testis fluid of rams. 7. Reprod. Fert. 17, 403.

Kormano, M., Koskmies, A. I. \& Hunter, R. L. (1971) The presence of specific proteins, in the absence of many serum proteins, in the rat seminiferous tubule fluid. Experientia, 27, 1461.

Niemi, M. \& Kormano, M. (1965) Histological demonstration of a C-esterase activity in the seminiferous tubules of the rat testis. F. Reprod. Fert. $10,49$.

ORTEC AN32 (1970) Techniques for high resolution electrophoresis. ORTEC Inc., Oak Ridge, Tennessee.

RoLSHOven, E. (1936) Ursachen und Bedeutung der intratubularen Sekretströmung im Säugerhoden. Z. Anat. EntwGesch. 105, 374.

Ross, M, H. \& LoNG, I. R. (1966) Contractile cells in human seminiferous tubules. Science, N.X. $153,1271$.

Setchell, B. P. (1969) Do Sertoli cells secrete the rete testis fluid? J. Reprod. Fert. 19, 391.

Setchell, B. P. (1970a) Testicular fuids. In: The Testis, Vol. I, p. 101. Eds. A. D. Johnson, W. R. Gomes and N. L. VanDemark. Academic Press, New York.

Setchell, B. P. (1970b) The secretion of fluid by the testes of rats, rams and goats, with some observations on the effect of age, cryptorchidism and hypophysectomy. F. Reprod. Fert. 23, 79.

Setchell, B. P. (1971) The secretion of fluid by the testis. Res. Reprod. 3, 1.

Streda, L. (1877) Ueber den Bau des Menschen-Hoden. Arch. mikrosk. Anat. EntwMech. 14, 17.

SuORANTA, H. (1971) Changes in the small blood vessels of the adult human testis in relation to age and some pathological conditions. Virchows Arch. path. Anat. Physiol. 352, 165.

Tillinger, K.-G. (1957) Testicular morphology. Acta endocr., Copenh., Suppl. 24, 30.

Tuck, R. R., Setchell, B. P., Wattes, G. M. H. \& Young, J. A. (1970) The composition of fluid collected by micropuncture and catheterization from the seminiferous tubules and rete testis of rats. Pflügers Arch. ges. Physiol. 318, 225.

Voglmayr, J. K., Waites, G. M. H. \& Setchele, B. P. (1966) Studies on spermatozoa and fluid collected directly from the testis of the conscious ram. Nature, Lond. 210,861.

von Miralkovics, V. (1873) Beiträge zur Anatomie und Histologie des Hodens. Ber. Verh. sächs. Akad. Wiss. 24, 217.

Young, W. G. (1933) Die Resorption in den Ductuli efferentes der Maus und ihre Bedeutung für das Problem der Unterbindung im Hoden-Nebenhodensystem. Z. Zellforsch. mikrosk. Anat. 17, 729. 